\title{
Determining Optimal Macroprudential Instruments
}

\author{
Kay E. Winkler \\ New Zealand Institute for the \\ Study of Competition and Regulation (ISCR) \\ Working Paper, February 2015
}

\section{$1 \quad$ Introduction}

Central banks and governments around the world are currently facing challenging economic and monetary issues from the aftermath of the 2007 credit crisis. Eight years after the start of the recession, the global economy still struggles to cope with the results of the overblown credit market.

The reasons for the credit crisis are well understood. Beginning in the late 1990s, The United States government pushed a policy of homeownership that allowed even the lowest income households to acquire real estate. This policy came with low interest rates and lax lending standards. Consequently, housing demand rose, leading to increasing house prices and credit volume. A housing bubble formed that eventually burst when interest rates were adjusted to counter inflation. The Federal Reserve Bank increased interest rates between 2004 and 2006 from about 1\% to $5.25 \%$. A large proportion of mortgage debtors with adjustable rates could not keep up and defaulted. The financial system had not built up sufficient reserves to cope with the high default rate. Progressively, banks had securitized mortgages to the private, unregulated market that to a large extent was financed with debt itself. The risk of a large-scale default in mortgages was not accounted for in the financial market as a whole, although banks seemed safe, according to their individual balance sheets.

The macroeconomic literature acknowledges the failure of microprudential and monetary policy to provide measures to avoid the formation of excessive credit and to ensure that financial institutions can cope with a bursting credit bubble. It is now agreed that macroprudential instruments are needed, which take potential spillover effects between financial intermediaries into account and address systemic risks to the banking sector. 
Which macroprudential tools are effective and what welfare effects stem from them, is, however, not agreed upon. The literature makes several attempts to identify appropriate macroprudential policy options, but is still undecided about the optimal set of regulatory instruments.

This paper provides an overview of the state of the art of macroprudential regulation as deliberated in the literature. It summarizes the findings of select papers that reflect the course of the discussion on effective policies to counter credit bubbles and to stabilize the financial system. The set of papers presented here is by no means intended to be comprehensive, but rather meant to be a representative snapshot of the current debate.

The paper starts with the general rationale of macroprudential regulation and the importance of instruments dealing with systemic risk. The subsequent section includes issues that arise from mortgage lending practices. The associated risk is endemic for the recent crisis and therefore is an important parameter for determining the effectiveness of policy options. The paper concludes by distilling the common findings and by proposing themes for future research.

\section{Rationale of Macroprudential Regulation}

As it has been increasingly acknowledged that microprudential policies addressing idiosyncratic risks of financial intermediaries are not sufficient, the literature started to look at policy options to mitigate systemic risk of excess credit. The dynamics of boom and bust cycles is particularly important, and the need for countercyclical tools is identified. While earlier work focuses on the need of capital requirements to address systemic risks, later papers consider additional instruments such as liquidity requirements or bank closure policies.

\subsection{Capital Requirements and Systemic Risk}

The role of regulation for capital ratios of banks is analysed by Berger et al. (1995). According to the authors, capital 'requirements' can result from market discipline or from government regulation. Under the condition of full information and complete markets, the Modigliani and Miller (1958) proposition refutes that firms can raise their value by changing their capital structure. Market prices will compensate for any leverage decision by the firm. The optimal capital structure is chosen as the cost of equity becomes higher with increased risk from leverage. The risk to shareholders 
increases with higher leverage, so that the cost of equity increases too, leaving the weighted average cost of financing constant. The assumption of a frictionless world needs to be adjusted for firms in general, taking taxes and costs of financial distress into account, as well as asymmetric information and transaction costs. Banks are in a particular situation that makes a departure from the Modigliani and Miller proposition even more valid than for other firms.

First, there is a safety net for banks that exists because the government has an interest to provide insurance for banks' risks. This safety net includes deposit insurance ${ }^{1}$, unconditional payment guarantees, and other bank safety regulation that does not directly affect the capital ratio. The market requirement for a certain ratio of equity to assets is lowered as banks are insulated from potential market discipline. The authors point to the historical evolution of bank capital ratios in the United States. The equity as a percentage of assets has been continuously lowered with the introduction of several bank safety regulations. The ratio dropped from over $50 \%$ in 1840 to $6-8 \%$ in the 1940 s (see Fig. 1). It stayed on this level until risk-based capital requirements were introduced in 1990, after which it raised slightly to consistently about $8 \%$.

Equity as percent of assets, 1840-1993 for U.S. commercial banks.

Source: Berger et al. (1995)

1 Deposit insurance exists for example in North America, the European Union, and Australia, but currently not in New Zealand. 
Second, banks are subject to capital regulation that has been introduced to protect the government from exposure to the risks of providing the safety net, and to protect the economy from negative externalities caused by bank failures. In other words, the authors regard capital regulation as a means to address idiosyncratic risks as well as systemic risks, and hence as a part of micro- and macroprudential policy. They note, however, that capital requirements are a rather blunt tool for controlling these risks. The value of equity and its variability is difficult to measure and monitor. Further, capital regulation may have unintended consequences. It may give incentives for some banks to increase their portfolio risks and their probability of failure. Allocative inefficiencies may arise as banks divert financial resources from their most productive use to off-balance sheet risks, such as securitization in form of off-balance sheet guarantees, which were not subject to capital requirements and increasingly used by banks in the 1980s. Another unintended outcome was observable in the 1990s when risk-based capital requirements were introduced after initiation of the Basel Accord. Banks shifted from loans to other assets such as Treasury securities. As a result, a contraction of bank lending, the 'credit crunch', occurred in the early 1990s.

\subsection{Credit Market Competition and Capital Regulation}

Allen et al. (2011) develop a simple model to show that discipline from the asset side incentivises banks to hold positive capital, regardless of regulatory requirements. In the model each bank lends to one firm for an investment project, which either is successful and yields an expected payoff or not. The model takes the amount of capital, the loan rate, the deposit rate and the unobserved effort of monitoring by the bank into account. For simplicity, the monitoring effort also represents the success probability of the financed project. Banks observe information about the firms and help to improve the firms' performance, or provide financial expertise. The bank may not be incentivized to monitor properly as monitoring is costly and cannot be observed by the borrowers. The bank can maximize profit by increasing either the loan rate or the capital.

The authors compare the results of the model for the case of an unregulated market and the case that the amount of capital is regulated. Both cases assume a perfectly competitive credit market. Under the scenario where no deposit insurance exists, the market solution induces banks to hold inefficiently high levels of capital 
when the return of the project is sufficiently high. Borrowers prefer banks to hold high levels of capital as a way to commit to high levels of monitoring. With lower project returns, the market solution (maximizing borrower surplus) coincides with the regulatory solution (maximizing welfare), so that the market solution is constrained efficient (efficient under incomplete markets). The result changes slightly if deposit insurance exists (i.e. the government guarantees the deposit rate if the bank goes bankrupt, and the deposit insurance is paid with lump sum taxes). Under this scenario, the market solution may entail lower levels of capital and monitoring. The market solution still may result in too much capital, or is constrained efficient coinciding with the regulatory solution. As a result, competitive credit markets may induce banks to hold positive levels of capital that sometimes can exceed socially optimal regulatory levels.

The authors also relax the assumption of perfect competition. If the bank operates as a monopolist, it will set the loan rate to the return of the project to maximize its profit, which gives it a high incentive to monitor. If no deposit insurance exists, the bank internalizes the cost associated with project failure and has the incentive to monitor efficiently. In contrast, under deposit insurance, the bank has no incentive to use any capital to commit to monitor. In that case, capital regulation can provide incentives to monitor. With intermediate market structures between perfect competition and monopoly (such as imperfect competition or oligopoly), the surplus from the lending contract is split between bank and borrowers, and the effects will remain. The more surplus banks obtain, the less capital they will use. The more surplus goes to borrowers, the more capital banks use.

The authors find empirical evidence for the validity of their model. Banks voluntarily hold high levels of capital above regulatory requirements, and changes in capital regulation do not affect capital structures of banks. Also, the variation of capital levels in accordance with the degree of competition has been found empirically.

The authors express some reservations for the model. Foremost, they acknowledge that the model disregards systemic risks and only covers idiosyncratic individual risks for banks that loans are not repaid. An additional role for regulations could stem from the fact that loan risks may spill over to other banks. The market 
solution would not internalize such a contagion risk. A regulator may therefore require higher levels of capital than obtained with the model.

\subsection{High-Quality Capital Requirements as Main Tool}

The importance of requiring that financial firms have more and higher-quality capital is stressed by Hanson et al. (2010). The authors identify two primary risks that call for macroprudential regulation: credit crunch and fire-sale effects. Facing microprudential capital requirements, banks may choose to cut lending in order to shrink their assets. This might result in a credit crunch with adverse effects for the economy. Financial firms may also choose to shrink their assets by dumping illiquid securities, e.g. toxic mortgage-backed securities. If all firms decide simultaneously on the same strategy, fire sales occur. Fire sales of securities make new loans more costly as well, which further deepens credit crunches.

To counter systemic risks, several macroprudential policy tools can be considered. According to the authors, capital requirements should be time-varying. In 'good times', banks should hold more capital in relation to total assets. In 'bad times', the capital ratio should be relaxed in order to avoid credit crunches. The authors note, however, that during the financial crisis of 2008 the regulatory capital requirement was in fact not the binding constraint. In the first quarter of 2010, the four largest U.S. banks had an average ratio of common equity to assets of $8.2 \%$, while the regulatory requirement was $6 \%$. The authors conclude that "the regulatory requirement in good times must substantially exceed the market-imposed standard in bad times" (p. 8). They also argue for a requirement of higher-quality capital. Common equity is friendlier to recapitalization than preferred stock, and should be the basis for calculating the capital ratio.

Another important policy consideration the authors make is the inclusion of the 'shadow banking system' in the regulation of financial markets. Excessive shortterm debt anywhere in the financial system and not only in the banking system can pose fire-sales and credit crunch problems. An increasing fraction of consumer and business loans are being securitized, for example in the form of asset-backed securities. Investors that acquire asset-backed securities finance them with short-term debt. The risks of loans are thus shifted from banks to highly-leveraged investors, such as hedge funds, that are not subject to banking regulation. 


\subsection{Systemic Risk and Regulation Design}

Acharya (2009) analyses the systemic risk of bank assets. Based on Allen and Gale (2000), the author constructs a multi-period general equilibrium model with many agents and many markets. The model allows two banks with limited liability to invest in safe or risky assets and to choose the industry of risky investments. The result of these investment decisions in the following period can be that both banks survive, both banks fail, or one bank fails and the other survives. The failure of one bank can create a "recessionary spillover" and increase the costs of the surviving bank, thus constitute a negative externality. In the case of such a negative externality from a default of one bank on the profitability of others, the model predicts a Nashequilibrium of the investment choices, in which each bank has a preference to survive when the other banks survive, and thus to fail when the other banks fail. As a consequence, banks' investment decisions tend towards a high correlation of their asset portfolios.

The author identifies a phenomenon he calls 'systemic risk-shifting'. Banks collectively increase the aggregate risk by investing in riskier asset classes and by pursuing highly correlated or overall poorly diversified investments. As the likelihood of failure of the banking system increases, risk-shifting is suboptimal for social welfare. In contrast, if the banks invested in the lowest level of risk and as little correlated as possible, the likelihood of joint failure would be minimized.

Based on these findings, the author discusses policy options for financial regulation. While a bank-closure policy that bails out failing banks is assumed to be ex post optimal, it creates moral hazard in the form of excessive risk-taking and will therefore not be ex ante optimal. To counteract this moral hazard, the policy may stipulate that bank owners upon bail out retain only a fraction of their equity claim. The higher this fraction, the greater is the forbearance towards the bank. If the forbearance policy is greater for joint failures than for individual failure, a systemic moral hazard is generated. The government insurance to banks in the form of greater forbearance under joint failure provides banks an incentive to have highly correlated asset portfolios, which manifests systemic risk-shifting. The author suggests implementing bank sales in closure policies to mitigate systemic risk. Bank sales would increase the charter-value of banks when they survive and others fail. The 
surviving banks would be able to acquire failed banks at a lower than their fair value. The preference for highly correlated portfolios would be reduced.

As to capital requirements, the author observes that such policies usually fail to address systemic risks. The collective incentives of banks remain unaffected. Rather, capital requirements should explicitly be based on inter-bank correlations. An optimal regulation would take account of both intra-bank and inter-bank correlations of market risks. Prudential regulation should require banks to hold greater capital against general risks, such as interest rates, foreign exchange rates, and industry, compared to idiosyncratic or specific risks (with the same risk level). Systemic risks would be reduced since banks are incentivised to be less correlated. The author also notes that there is a trade-off between diversification and correlation. More diversified banks have lower individual risks, but increase the systemic risks from correlation.

\subsection{Microprudential Regulation in a Dynamic Model}

De Nicolò et al. (2014) address the effect of banking regulation on welfare and bank efficiency. Although the authors investigate microprudential instruments, they take systematic macroeconomic risks into account. Unlike others, the authors combine capital regulation, liquidity requirements, and prompt corrective action (PCA) policies in a dynamic model. Capital regulation refers to a Basel II type capital ratio that is set by the regulator according to the bank's risk exposure. The capital ratio is the ratio of the book value of capital to that of loans. Liquidity requirements as introduced by Basel III refer to a minimum ratio of high quality liquid assets over the predicted net cash outflow over a 30-day period. PCA policies force a bank to liquidate assets or suspend payouts if capitalization falls below a pre-defined observed level. If the bank's ex post capital at the end of a period is negative, the distressed bank is closed and taken over by the deposit insurance agency; that is, the bank is expropriated from the shareholders and transferred to the government.

The authors assess the impact of these regulatory measures applying Monte Carlo simulations on different specifications. In comparison to unregulated banks, capital requirements increase banks' incentives to invest more in loans and to choose less debt. A mild capital requirement thus strengthens banks' liquidity positions in an economic downturn. In contrast, a liquidity requirement is more restrictive and forces banks to reduce both debt and lending. While in an economic upturn banks reduce 
lending significantly, in a downturn capital and liquidity ratios are not significantly different from those attained under capital regulation only. Under PCA, the correlation between lending, debt, capital, and liquidity ratios are similar to capital regulation, but banks retain more flexibility to not reduce lending as much.

Similarly, the authors find, from a welfare perspective, that banks with capital requirements lend more and have less debt, than unregulated counterparts. Mild capital requirements are welfare enhancing as they reduce the likelihood of bank default and banks increase lending. However, there is an inverted U-shaped relationship between capital requirements and welfare. If capital ratios are set too high, the optimal policy of banks is to reduce lending, which in turn reduces welfare. This suggests an optimal level of regulatory capital depending on the individual bank's characteristics.

When liquidity requirements are added, efficiency and welfare decline significantly. They undo the benefits of capital requirements and incentivise banks to reduce lending. Liquidity regulation thus results in safe, but very inefficient banks.

PCA, on the other hand, achieves increased lending and capital, as well as higher levels of efficiency and welfare relative to capital requirements only. Since PCA introduces contingencies based on observed equity, it provides stronger incentives to manage risks.

\section{$3 \quad$ Systemic Risks from Mortgage Lending}

Mortgages play a specific role in debt aggregation. Debtors and creditors assume real estate as a relatively low risk investment since the financed asset serves as a collateral with a long-term tendency to increase in value. Borrowers are often financially inexperienced, and tend to overestimate value appreciation of houses, especially in boom times. Confidence in the ability to repay and debt levels are therefore high. Whether the current debt cycle is excessive is difficult to detect a priori. Financial market regulation may reduce the risk of over-lending and the buildup of excessive debt.

The literature discusses the optimal mix of monetary and macroprudential policies to address specific risks from mortgage lending. The effects of loan-to-value or debt-to-income ratios are discussed. Methods to respond countercyclically to debt levels are evaluated. Conceptually, mortgage defaults are either seen as being 
produced by exogenous shocks, or as being part of the aggregation of endogenous risks.

\subsection{Loan-to-Value Ratio and Mortgage Valuation}

Krainer et al. (2009) construct an equilibrium valuation model to test whether the U.S. housing market crisis beginning in 2006 was caused by a failure of the market to accurately value mortgages. They find that this was not the case, but rather that market participants were "simply unlucky". Forecasts generated by an accurate model would not be able to avoid high mortgage default rates due to extreme realizations of house price shocks. The model is successful in showing that mortgage valuation depends on initial loan-to-value ratios, and the authors conclude that there is no evidence of systematic under-pricing of default risk in the period preceding the housing crisis.

Implementing data from conventional loans originated for home purchases in California between 2000 and 2007 confirms the model's prediction that mortgage pricing in fact depends on loan-to-value ratios. High loan-to-value mortgages entail a higher risk of default than low loan-to-value mortgages. For both fixed-rate mortgages and adjustable-rate mortgages, high loan-to-value mortgages have significantly higher default rates.

The empirical analysis reveals further details on the housing market crisis. The average loan size increased from US\$ 290,000 in 2002 to $\$ 461,000$ in 2006. The average loan-to-value ratio remained unchanged at about $75 \%$. The authors note that the true aggregate leverage was higher than this figure, as it is only computed from first lien mortgages. High loan-to-value borrowers, however, frequently do not borrow the full amount using a single mortgage, but rather combine the first lien mortgage with a second lien. Risky borrowers, as measured by their credit score (FICO score), are more likely to receive high loan-to-value mortgages; and high loanto-value mortgages are more likely adjustable-rate than fixed-rate mortgages.

The proportion of subprime labelled mortgages almost tripled from $3 \%$ in 2002 to $8 \%$ in 2006. Also jumbo loans (mortgages exceeding conforming loan limits) increased in line with house pricing from $29 \%$ to $43 \%$. While total securitization rates remained stable at about $84 \%$, non-agency securitization (i.e. securities issued by private entities) rose from $27 \%$ to $57 \%$. After house prices in California peaked in 
2006, they fall by more than $25 \%$ until 2008. Simultaneously, delinquency rates dramatically surged upward.

The major shortcoming of the analysis of Krainer et al. (2009) is that their model assumes an exogenous house price shock, although they acknowledge that lax underwriting standards possibly contributed to the price run-up. The model is not able to detect a systemic link between mortgage underwriting practices and house prices. As the model demonstrates, the lenders' assessment of individual mortgage risks can be accurate and sufficiently evaluate individual mortgages according to the risk of default. The accumulated risk of the whole financial industry is, however, not revealed. The growth in house prices due to laxer borrowing standards, the accumulation of high risk borrowers, and the consequential risk of a large portion of borrowers to default, is not captured by the model as an endogenous systemic risk.

\subsection{Excess Volatility of House Prices}

According to Gelain et al. (2013), the U.S. financial and economic crisis that started in December 2007 was fuelled by excessive household debt that stemmed from a house price bubble. They identify a self-enforcing feedback loop in which new homebuyers had easy access to mortgages that led to an excessive run-up in house prices. Such bubbles are difficult to detect prior to their burst because asset prices seem to be justified by fundamental factors such as economic growth.

In order to identify policy options that may avoid bubbles, Gelain et al. (2013) design a model that captures boundedly rational expectations of homebuyers to explain excess volatility in house prices. Standard dynamic stochastic general equilibrium (DSGE) models assume fully rational expectations and treat the decline of collateral asset values as an exogenous shock, rather than a burst of a bubble that stems from systemic failures of debtors to accurately estimate the price development. The authors point out that standard DSGE models would "imply that the decline in U.S. house prices since 2007 was caused by something akin to a nationwide infestation of wood termites" (p. 224). Instead, their model integrates subjective forecasts of agents as an endogenous source of volatility.

In their adaptation of the DSGE model, Gelain et al. (2013) allow for hybrid expectations: $70 \%$ of households are fully rational, while $30 \%$ employ a movingaverage forecast rule that embeds a partially self-fulfilling prediction of future house 
prices on the basis of past data. The use of a simple forecasting model acknowledges the fact that the increase of U.S. house prices and credit was linked to the influx of new and unsophisticated homebuyers. Excess volatility is measured relative to fluctuations under the same model with fully rational expectations. A simulation using the model generates volatilities of house prices and household debt that are inflated by about $50 \%$ under hybrid expectations.

The authors assess several policy options to dampen the observed fluctuations. The monetary policy measure to adapt interest rates in response to house-price growth shows some benefits under rational expectations, which are limited under hybrid expectations. Similarly, benefits from interest rate responses to credit growth completely disappear under hybrid expectations. Under both expectation regimes, interest rate policies magnify inflation volatility, the effect of which is more severe under hybrid expectations. Thus, the outcome of monetary policy may depend on the nature of agent expectations. Fully rational households understand that increased borrowing will result in higher interest rates that in turn increase the cost of borrowing. Boundedly rational households using a moving average of past values to forecast prices will not take the central bank's interest policy into account.

As to macroprudential policy, the authors find that a reduction of the loan-tovalue ratio from 0.7 to 0.5 substantially decreases volatility of household debt, but slightly magnifies output volatility. Other volatility effects are small. Policy makers might have to weigh the positive effect of lower loan-to-value ratios against the negative effects of restricting households in taking up loans.

A further macroprudential policy option would be a generalized borrowing constraint, by which lenders are required to place a substantial weight on the borrower's wage income. This would be a more prudent criterion than loan-to-value ratios because income is less subject to bubbles than asset values. It also effectively achieves a counter-cyclical loan-to-value ratio and in this way serves as an "automatic stabilizer" for household debt. The borrowing constraint places a weight of $75 \%$ on the borrower's wage income for lending decisions, and $25 \%$ on the expected value of housing collateral, leaving the steady-state loan-to-value ratio unchanged. Under hybrid expectations, the borrowing constraint reduces volatility of house prices and household debt, while mildly reducing volatilities of other values, or leaving them unchanged. The magnification of inflation volatility, as caused by interest rate 
policies, is avoided. The authors conclude that a generalized borrowing constraint is the most effective tool for dampening excess volatility. They observe that such a lending behaviour is "basically the opposite of what was observed during the U.S. housing boom of the mid-2000s" (p. 268).

\subsection{Mitigation of News-Shock Driven Cycles}

A model for boom-bust cycles in credit and house prices that are driven by news shocks is the focus of Lambertini et al. (2013). News shocks are changes in fundamental macroeconomic conditions that rational forward-looking agents take into account. For example, an anticipated reduction in interest rates lets agents expect that borrowing costs fall and house prices rise. As a consequence, housing demand, mortgage debt and house prices increase immediately. Such upward pressure can result from news on productivity or policy rates. Busts follow if the news is later not realized. The model is based on two types of households, namely savers and borrowers, that differ in their discount factors, which induces credit flows between the two types. The model economy features a non-durable goods sector, a non-residential investment sector, and a residential investment sector. Interest-rates vary according to the policy of the monetary authority. The model shows that boom-bust cycles in the housing market can be explained with expectations of future developments in different sectors of the economy and in monetary policy.

Determining the effects of certain policy measures on the welfare of savers and borrowers, the authors investigate the design of an optimal policy rule. They find that a policy rule that sets the loan-to-value ratio in a countercyclical fashion can be welfare improving compared to a constant ratio. However, if the loan-to-value ratio responds to either house prices or GDP growth, a trade-off between the welfare of borrowers and that of savers exists. In contrast, an optimized loan-to-value ratio that responds to credit growth is Pareto improving.

The authors further investigate the effect of an interest-rate rule that responds to credit or house-price growth. They find that an interest-rate rule that responds to credit growth is superior as it improves welfare more and better reduces volatility of credit and house prices. Such an interest-rate rule is also preferred by both types of households, compared to the optimized loan-to-value ratio. 
Finally, the authors evaluate a combination of macroprudential and monetary policy rules. They conclude that a countercyclical loan-to-value ratio in addition to an interest-rate response to credit growth is socially optimal because of the large improvements for borrowers.

\subsection{Empirical Evidence on Effectiveness of Policy Instruments}

Crowe et al. (2013) assess the effectiveness of several policy instruments to deal with real estate booms. The authors note that traditional macroeconomic policies were ill equipped to address the detrimental effects of the U.S. real estate bubble that led to the deepest recession since the Great Depression. An optimal policy would have two primary objectives, namely to prevent the build-up of excessive leverage from real estate booms, and to mitigate the effects of busts by strengthening the resilience of the financial system. The authors recognize that there is no 'silver bullet', as practical and conceptual difficulties exist with each policy measure. They consider empirical evidence from monetary policies, fiscal tools, and macroprudential regulation.

From an empirical analysis of 19 advanced countries, the authors find that "monetary policy could in principle stop a boom, but at very high costs." At first, they find little evidence of a correlation between house prices and interest rates or other monetary measures. This can, however, be attributed to deflationary effect from the rapid decline in import prices for goods from low-cost emerging market economies, such as China. When accounting for import prices, the relationship becomes statistically significant. The robustness and statistical significance improves further when house price growth is compared to GDP deflator inflation based Taylor residuals (i.e., inflation as expressed by GDP deflators measuring 'discretionary' monetary policy): looser monetary policy tends to result in an increase in house prices. The relationship is, however, weak, and policymakers would have to drastically increase interest rates to experience a meaningful impact on house prices. Large effects on output and inflation would follow. Referring to the experiences in Australia and Sweden, the authors conclude that marginal changes in interest rates are unlikely to affect a real estate boom.

As to financial instruments, the authors find that transaction taxes empirically have no clear relationship with house prices. Higher rates of property taxes, in 
contrast, could limit housing booms and short-term volatility around an upward trend in prices. Neither transaction taxes nor property taxes directly target credit and leverage, though, and thus fail to provide a link to the source of vulnerability of the financial system. Changing the tax deductibility of mortgage interest ${ }^{2}$ could affect loan-to-value ratios, but would be difficult to change in a cyclical manner and thus be more appropriate for a one-off reform.

Finally, the authors assess the macroprudential tools of capital requirements, dynamic provisioning, loan-to-value and debt-to-income ratios. The empirical evidence on capital requirements is mixed. Tighter capital requirements were successful in some countries, and failed in others to stop booms and post-boom damage. Even in countries experiencing some benefit, real estate appreciation and credit growth remained strong. Borrowers and lenders may circumvent such policy tools and find other, less regulated types of credit.

Evidence for dynamic provisioning suggests that such policy measures are effective in strengthening the overall stability of the financial system, but are not suited to avoid real estate booms. Requiring an extra buffer of loan loss provisions during good times can help to cope better with potential losses, but is unlikely to increase the cost of credit and thus to stop a boom.

Loan-to-value ratios appear to restrain house pricing. The authors find in a simple cross-section analysis of 21 countries for the years 2000-2007 that maximum loan-to-value limits are positively correlated with house price appreciation. A weaker correlation between loan-to-value ratios and house price increases is found for U.S. states in the period from 1978-2008. Practical experience with changes in mandatory loan-to-value ratios suggests that they can be effective for short periods. Similar patterns can be established for debt-to-income ratios.

\subsection{Monetary and Macroprudential Instruments in Model of Euro Area}

An optimal mix of monetary and macroprudential policy options is assessed by Quint and Rabanal (2014). They model the situation in the Euro area, in which the European Central Bank (ECB) sets monetary policies for the whole currency union. As a consequence, country-specific economic cycles cannot be addressed with

2 Mortgage interest payments for the taxpayer's personal residence are not tax deductible in most countries, but they are in the United States (where additional tax incentives for home ownership exist). 
monetary policy within the currency union. The model allows national central banks to introduce macroprudential instruments that differ between countries. These additional instruments can potentially contribute to stabilizing boom and bust cycles. With the option of country-specific policies, the model extents the approach in Kannan et al. (2012), but reaches similar results.

The authors construct an estimated dynamic stochastic general equilibrium (DSGE) model with two countries, two sectors, and two types of agents. One country resembles the core of the currency union and is represented by aggregated data for France and Germany. The other country signifies the periphery of the currency union and is represented by the GIIPS nations (Greece, Ireland, Italy, Portugal, and Spain). The two sectors comprise non-durables and durables respectively, the latter of which can be understood as housing. Savers and borrowers are the two types of agents. The Bayesian estimation of the model parameters is based on data from the sample countries in the period from 1995 to 2011. Five observables are used, namely real private consumption spending, real residential investment, the Harmonised Index of Consumer Prices, housing prices, and outstanding debt for households.

The model enables the authors to experiment with different policy configurations. The performance of different policy rules is analysed using the estimated parameter values and by incorporating several shock processes (technology, preference, and financial shocks). First, the authors find that optimizing over the coefficients of the estimated Taylor rule (which reacts to union-wide consumer price index (CPI) inflation and real output growth) increases welfare of all households slightly, but more so for savers while borrowers in the periphery lose slightly. Second, monetary policy of the ECB is allowed to react to union-wide credit indicators, i.e. nominal credit growth and credit-to-GDP ratio. Welfare improves with reacting to nominal credit growth, but this is due to welfare increases of savers (borrowers' welfare declines). Reacting to the credit-to-GDP ratio does not yield a welfare improvement. Third, macroprudential policy measures are introduced that respond countercyclical to domestic developments in each country. The authors do not specify the sort of policy, and only define it as influencing the lending-deposit spread by affecting the fraction of liabilities (deposits and bonds) that financial intermediaries can lend. They suggest measures like additional capital surcharges, liquidity ratios, loan-loss provisions, reserve requirements, or providing of liquidity (in case that the 
lending-deposit spread is to be reduced). The authors find that a macroprudential policy that reacts to nominal credit growth improves welfare for both types of agents, but does not maximize union-wide welfare. Reacting to the credit-to-GDP ratio yields the highest welfare, but is highly divisive, since savers (especially in the periphery) benefit greatly, while borrowers lose substantially.

As in Kannan et al. (2012), the optimal responses of monetary and macroprudential authorities vary according to the source of the shock. When it is optimal to reduce the countercyclical behaviour of the lending-deposit spread, as in the case of housing demand or risk shocks, macroprudential policies may be welfare enhancing. Under technology shocks, however, the optimal policy to any credit aggregate is not to react with macroprudential tools, since this could magnify the countercyclical behaviour of the lending-deposit spread.

\section{Conclusion}

This survey of macroprudential policy research reveals that several policy instruments have the potential to mitigate systemic risks from credit cycles. Although there is no conclusive agreement on the optimal policy, some insights can be obtained that narrow down the choices of effective regulatory measures. Most likely, a combination of several tools results in an effective oversight.

Capital requirements are a limited means to counter systemic risk. Market discipline already incentivizes banks to maintain a certain capital ratio. In the U.S., the voluntary capital ratio was for over 50 years only marginally under the regulatory requirement that was introduced in 1990. No major credit bubble had occurred during that time. The recent credit crisis did happen despite existing capital regulation. Other factors are clearly relevant for the stability of the financial system. Capital requirements can have unintended consequences, such as diversion of financial resources to riskier asset classes or increased securitization to move credit off the balance sheet. There seems to be an optimal degree of capital ratios: too extensive capital requirements can be as welfare decreasing as too little.

The increased use of securitization is a major contributor to the credit crisis. The possibility for banks to move credit positions to unregulated intermediaries creates moral hazard. Monitoring incentives for banks are reduced, and underestimation of aggregate risks may occur. The fact that debt based securities can 
be financed with debt escalates risk and increases moral hazard. Capital regulation must address securitization of mortgages in order to be effective. The literature fails so far to produce specific recommendations to this extent.

Bank closure policies are an important piece in the set of macroprudential instruments. Although a bail out policy may be ex post optimal, it creates moral hazard in the form of excessive risk-taking. Bank sales or closure policies depending on capital levels may correct incentives of banks to effectively monitor risks.

Monetary policies alone are not able to address risks from credit bubbles effectively. Given that homebuyers to a large extent do not make fully rational choices, interest rate policies may severely magnify inflation volatility. Interest rate policies can be optimized by responding to credit growth.

Low loan-to-value ratios may combat excessive housing price appreciation and debt bubbles from homeownership. Regulating loan-to-value ratios in a countercyclical fashion according to credit growth may further improve welfare. Similarly, imposing debt-to-income limits can achieve stability in the financial system. Income is not as subject to cycles as asset prices. Also, loan-to-value ratios may be easy to circumvent if several sources of credit are available. Income ratios are de facto stricter. A combination of both instruments seems to be an effective way to address credit cycles.

As a difficulty for policy makers, macroprudential policies appear to be optimal when set in a countercyclical manner and depending on the source of shocks. Cycles and the nature of shocks are, however, difficult to detect in advance. A balance must be found between the avoidance of worst-case risks and the over-restriction of market opportunities. Therefore, the design of static macroprudential requirements may be desirable that inherently have countercyclical effects, and err on the side of avoidance of bubbles. Further research could concentrate on finding such solutions.

Some important issues might be addressed in future research projects. First, macroprudential policy must be seen in the context of overall financial policy (as to the multidimensional complexity of market failures, see De la Torre and Ize, 2013). There is little use of prudential tools if the government decides to foster homeownership by all means, ignoring any stability considerations. The most effective macroprudential instruments would easily be overruled by such political 
attitudes. Similarly, all financial policy instruments have to be seen together as they interact. Macroprudential, microprudential, monetary, and tax rules all influence each other. Further, the various rules are usually governed by different authorities, which are motivated by different policy objectives. This is particularly prevalent in the Euro area, but to various degrees also in other jurisdictions.

Second, there seems to be an optimal level of credit. The notion that more lending is always better is not reasonable. Too little credit might stifle the economy. But too much credit obviously creates even greater problems, as demonstrated by the credit crisis. The almost paranoid avoidance of any reduction in credit volume contradicts the goal of financial stability. Again, monetary approaches such as quantitative easing to avoid credit crunches can accelerate the problem financial market regulation initially attempted to solve. Other instruments to enhance productivity may be more effective and less costly, such as reductions in consumption taxes that are counter financed with property or wealth taxes. A holistic research on financial market regulation may yield optimal policy choices.

Third, next to spill-over effects from one regulatory sector to another, intercountry effects need to be taken into account in a globalized economy as well. Regulation in one country does not protect the economy from excessive credit aggregation since financial intermediaries are globally interconnected. Banks can engage in global interbank lending and may have an international organisational structure of branches or subsidiaries in several countries that could affect the outcome of macroprudential regulation (Danisewicz et al. 2014). Finding a policy that is accepted in all major economies adds another dimension of difficulty. 


\section{References}

Acharya, V. V. (2009). A theory of systemic risk and design of prudential bank regulation. Journal of Financial Stability, 5, 224-255.

Allen, F., Carletti, E., \& Marquez, R. (2011). Credit market competition and capital regulation. The Review of Financial Studies, 24(4), 983-1018.

Allen, F., \& Gale, D. (2000). Bubbles and crises. The Economic Journal, 110, 236255.

Berger, A. N., Herring, R. J., \& Szegö, G. P. (1995). The role of capital in financial institutions. Journal of Banking and Finance, 19, 393-430.

Crowe, C., Dell'Ariccia, G., Igan, D., \& Rabanal, P. (2013). How to deal with real estate booms: Lessons from country experiences. Journal of Financial Stability, 9, 300-319.

Danisewicz, P., Reinhardt, D., \& Sowerbutts, R. (2014). On a tight leash: Does banks' organizational structure matter for macroprudential spillovers? Working Paper. Retrieved from http://ssrn.com/abstract=2534525.

De la Torre, A., \& Ize, A. (2013). The foundations of macroprudential regulation: A conceptual roadmap. Working Paper No. 6575. The World Bank. Retrieved from http://ssrn.com/abstract=2311108.

De Nicolò, G., Gamba, A., \& Lucchetta, M. (2014). Microprudential regulation in a dynamic model of banking. Review of Financial Studies, 27(7), 2097-2138.

Gelain, P., Lansing, K. J., \& Mendicino, C. (2013). House prices, credit growth, and excess volatility: Implications for monetary and macroprudential policy. International Journal of Central Banking, June, 219-276.

Hanson, S. G., Kashyap, A. K., \& Stein, J. C. (2010). A macroprudential approach to financial regulation. Working Paper No. 10-29. University of Chicago, Booth School of Business. Retrieved from http://ssrn.com/abstract=1708173.

Kannan, P., Rabanal, P., \& Scott, A. M. (2012). Monetary and macroprudential policy rules in a model with house price booms. The B.E. Journal of Macroeconomics, 12(1), 1-42.

Krainer, J., LeRoy, S. F., \& O, M. (2009). Mortgage default and mortgage valuation. Working Paper 2009-20. Federal Reserve Bank of San Francisco. Retrieved from http://www.frbsf.org/economic-research/files/wp09-20bk.pdf.

Lambertini, L., Mendicino, C., \& Punzi, M. T. (2013). Journal of Economic Dynamics \& Control, 37, 1500-1522.

Modigliani, F., \& Miller, M. (1958). The cost of capital, corporation finance, and the theory of investment. American Economic Review (June), 261-297.

Quint, D., \& Rabanal, P. (2014). Monetary and macroprudential policy in an estimated DSGE model of the Euro area. International Journal of Central Banking, June, 169-236. 